\title{
The Effect of Tocilizumab on Inflammatory Markers in Survivors and Non-survivors of Severe COVID-19
}

\author{
Said Amin ${ }^{1}$, Fawad Rahim¹, Sher Bahadur ${ }^{2}$, Mohammad Noor ${ }^{1}$, Afsheen Mahmood $^{3}$ and Huma Gul ${ }^{4}$ \\ ${ }^{1}$ Department of Medicine, Hayatabad Medical Complex, Peshawar, Pakistan \\ ${ }^{2}$ Department of Research, Khyber Institute of Child Health, Hayatabad, Peshawar, Pakistan \\ ${ }^{3}$ Department of Physiology, Khyber Girls Medical College, Peshawar, Pakistan \\ ${ }^{4}$ Department of Pharmacology, Khyber Girls Medical College, Peshawar, Pakistan
}

\begin{abstract}
Objective: To determine the effects of tocilizumab (TCZ) on inflammatory markers, laboratory indices; and short-term outcome in patients with severe COVID-19.

Study Design: Cross-sectional analytical study.

Place and Duration of the Study: Hayatabad Medical Complex, Peshawar, Pakistan from $10^{\text {th }}$ June till $31^{\text {st }}$ August 2020.

Methodology: Fifty-four patients with severe COVID-19 fulfilled the inclusion criteria and were included. All patients had received TCZ (4 mg/kg) in addition to standard treatment. Serum C-reactive protein (CRP), lactate dehydrogenase (LDH), Ddimer levels, full blood count, and liver function tests (LFTs) were checked before and 24 hours after receiving TCZ. Short-term outcome, defined as survival at day 28, was determined from hospital record/telephonic contact. Paired t-test was employed to assess the statistical significance of mean differences between the pre- and post-TCZ variables, considering a $p$-value of $<0.05$ as significant.

Results: Overall, the mean pre- and post-TCZ CRP was $18.7 \pm 10.7$ and $10.2 \pm 8.6 \mathrm{mg} / \mathrm{dl}$ ( $\mathrm{p}<0.001)$. It was $18.0 \pm 10.3$ and $10.3 \pm 8.8 \mathrm{mg} / \mathrm{dl}(\mathrm{p}=0.003)$ in survivors; and $19.4 \pm 11.4$ and $10.2 \pm 8.7 \mathrm{mg} / \mathrm{dl}(\mathrm{p}=0.005)$ in non-survivors, respectively. Overall, mean D-dimer level decreased from $12.5 \pm 23$ to $10.3 \pm 12.2 \mu \mathrm{g} / \mathrm{ml}$ following TCZ ( $p=0.643$ ); it decreased from $15.8 \pm$ 29.8 to $11.4 \pm 10.6 \mu \mathrm{g} / \mathrm{ml}(p=0.612)$ in survivors; and $9.0 \pm 12.8$ to $9.2 \pm 14.1 \mu \mathrm{g} / \mathrm{ml}(p=0.961)$ in non-survivors, respectively. There were no significant differences in the pre- and post-TCZ LDH levels overall and between the groups. The 28 -day mortality was $46.3 \%$.
\end{abstract}

Conclusion: Tocilizumab results in a significant reduction in CRP, while mean change in LDH and D-dimers was not substantial. The mean change in inflammatory markers did not predict survival.

Key Words: Tocilizumab, COVID-19, Biomarkers, Outcome, Mortality.

How to cite this article: Amin S, Rahim F, Bahadur S, Noor M, Mahmood A, Gul H. The Effect of Tocilizumab on Inflammatory Markers in Survivors and Non-survivors of Severe COVID-19. J Coll Physicians Surg Pak 2021; 31(JCPSPCR):CR7-CR10.

\section{INTRODUCTION}

In December 2019, the novel virus, SARS-CoV-2, emerged from China (Wuhan City) and reached all over the world; ${ }^{1}$ wherein, on $11^{\text {th }}$ March it was declared as a global pandemic by World Health Organization (WHO). ${ }^{2}$ The symptoms of COVID-19 vary from mild flu, fever, cough, myalgia to severe pneumonia, and acute respiratory distress syndrome. ${ }^{3}$ High levels of different cytokines correlate with the disease severity of COVID-19. ${ }^{4}$

Correspondence to: Dr. Fawad Rahim, Department of Medicine, Hayatabad Medical Complex, Peshawar, Pakistan

E-mail: drfawadrahim@outlook.com

Received: September 17, 2020; Revised: November 18, 2020;

Accepted: December 01, 2020

DOI: https://doi.org/10.29271/jcpsp.2021.JCPSPCR.CR7
The cytokine storm, especially high IL-6 concentration, contributes to injuries to lung tissues leading to respiratory distress. ${ }^{5,6}$ Interleukin-6 also decreases the immunity in patients against SARS CoV-2; and hence, proposed as the main predictor of mortality in cases with COVID-19.

Blockade of IL-6 receptors results in an improvement in the biochemical markers, especially inflammatory markers like LDH, serum ferritin, CRP, and D-dimer level. ${ }^{4}$ Due to lack of specific effective treatment, investigators have used different monoclonal antibodies for the treatment of severe COVID-19. ${ }^{8}$

Tocilizumab, a recombinant humanised monoclonal antibody against IL- 6 receptors, attracted clinicians for the treatment of COVID-19. ${ }^{9}$ Similarly, in Pakistan after reporting the first case of COVID-19 on February 26, 2020, tocilizumab was in use for severe COVID-19 as an off label medicine and later approved on $4^{\text {th }}$ June 2020 by the Drug Regulatory Authority of Pakistan. ${ }^{10}$

There are conflicting reports of the effect of TCZ on inflamma- 
tory markers and laboratory indices in severe COVID-19. ${ }^{11,12}$ The contradictory results from different study populations compelled the authors to generate local evidence of the effects of TCZ in severe COVID-19.

The aim of this study was to determine the effects of TCZ in the treatmentofsevereCOVID-19 regarding its effectson inflammatory markers among survivors and non-survivors.

\section{METHODOLOGY}

Ethical approval was obtained from the Institutional Review Board of Khyber Girls Medical College, Peshawar to carry out this cross-sectional analytical study. The requirement for patient consent was waived off. It was conducted at Hayatabad Medical Complex (HMC), Peshawar, Pakistan. Hayatabad Medical Complex is the only public sector tertiary care hospital with 128 high dependency beds and a 14-bedded intensive care unit dedicated to COVID-19 patients.

All patients with severe COVID-19 as per WHO criteria, who had received $\mathrm{TCZ}(4 \mathrm{mg} / \mathrm{kg})$ were part of the study. ${ }^{13}$ The eligibility criteria of HMC for TCZ was any patient with severe COVID-19 having hypoxemia (need for supplemental oxygen to maintain oxygen saturation $>92 \%$ ) and one of the following laboratory abnormalities: CRP more than $10 \mathrm{mg} / \mathrm{dl}$ or more than $5 \mathrm{mg} / \mathrm{dl}$ but doubled in the past 48 hours (cut off normal for CRP at the laboratory of Hayatabad Medical Complex (HMC), Peshawar, 0.5 $\mathrm{mg} / \mathrm{dl}), \mathrm{LDH}$ more than $250 \mathrm{U} / \mathrm{L}$ and D-dimer greater than 1 $\mu \mathrm{g} / \mathrm{ml}$. As per Hospital Guidelines, COVID-19 patients with HIV, cirrhosis, end-stage renal disease, inflammatory bowel disease, chemotherapy, clinically overt bacterial or fungal infections, and known drug hypersensitivity were not eligible to receive TCZ. Additionally, patients with neutrophil count less than $1.5 \times 10^{9} / \mathrm{L}$, platelet count less than $40 \times 10^{9} / \mathrm{L}$, and alanine transaminase level more than 1.5 times upper limit of normal (40 IU/L) were also excluded.

A total of 54 patients received TCZ as per hospital guidelines and were part of the study. All patients received standard treatmentfor COVID-19 as per approved hospital guidelines.

Data regarding inflammatory markers and laboratory indices of interest included serum CRP, LDH, D-dimer, full blood count, and liver function tests carried out before and 24 hours after receiving $T C Z$ were retrieved from the hospital information system (HIS). Short-term outcome was defined as survival on day 28 and was determined from hospital record / telephonic follow-up. The study variables were recorded on a structured proforma.

The data were analysed in SPSS version 21. Qualitative data like gender, comorbidities, and outcome were expressed as frequency and percentages, while quantitative variables like age and inflammatory markers were calculated as mean \pm S.D. Chi-square test was employed to assess the statistical significance of differences in 28-day mortality among patients on different modes of oxygen delivery. Paired t-test was employed to assess the statistical significance of mean differences between the pre-TCZ and post-TCZ variables, considering a Pvalue of $<0.05$ as significant.

\section{RESULTS}

Out of 54 participants, 35 (64.8\%) were males. The majority of the patients $(n=22,40.7 \%$ ) belonged to the age group 51 to 60 years. The predominant comorbidities were diabetes in 21 (38.9\%) and ischemic heart disease in 19 (35.2\%) patients. The demographic profile of the study population is presented in Tablel.

Table I: Demographic parameters of the study population.

\begin{tabular}{|l|l|}
\hline Parameters & $\begin{array}{l}\text { COVID - 19 } \\
\text { (n=54) }\end{array}$ \\
\hline Age, mean (SD), years & $57.3 \pm 10.1$ \\
\hline Age groups, No. (\%) & $3(5.6 \%)$ \\
\hline 31 to 40 years & $11(20.4 \%)$ \\
\hline 41 to 50 years & $22(40.7 \%)$ \\
\hline 51 to 60 years & $13(24.1 \%)$ \\
\hline 61 to 70 years & $5(9.3 \%)$ \\
\hline 71 to 80 years & $35(64.8 \%)$ \\
\hline Gender, No. $(\%)$ & $19(35.2 \%)$ \\
\hline Male & $21(38.9 \%)$ \\
\hline Female & $19(35.2 \%)$ \\
\hline Co-morbidity, No. (\%) & $16(29.6 \%)$ \\
\hline Diabetes & $7(13 \%)$ \\
\hline Ischemic heart disease & \\
\hline Hypertension &
\end{tabular}

Table II: Mean values and statistical significance of inflammatory markers and blood indices.

\begin{tabular}{|l|c|c|c|}
\hline Laboratory parameters & $\begin{array}{c}\text { Pre-TCZ } \\
\text { Mean } \pm \text { SD }\end{array}$ & $\begin{array}{c}\text { Post-TCZ } \\
\text { Mean } \pm \text { SD }\end{array}$ & p-value \\
\hline CRP $(\mathrm{mg} / \mathrm{dl})(\mathrm{n}=46)$ & $18.7 \pm 10.7$ & $10.2 \pm 8.6$ & $<0.001$ \\
\hline D-Dimers $(\mu \mathrm{g} / \mathrm{ml})(\mathrm{n}=25)$ & $12.5 \pm 23.0$ & $10.3 \pm 12.2$ & 0.643 \\
\hline LDH $(\mathrm{U} / \mathrm{L})(\mathrm{n}=33)$ & $719.8 \pm 302.2$ & $729.8 \pm 372.2$ & 0.800 \\
\hline TLC $\left(\times 10^{9} / \mathrm{L}\right)(\mathrm{n}=50)$ & $14.8 \pm 5.1$ & $13.6 \pm 5.1$ & 0.201 \\
\hline Neutrophils $(\%)(\mathrm{n}=54)$ & $88.6 \pm 14.8$ & $83.1 \pm 17.3$ & 0.010 \\
\hline Hemoglobin $(\mathrm{g} / \mathrm{dl})(\mathrm{n}=54)$ & $13.1 \pm 2.1$ & $12.8 \pm 2.1$ & 0.091 \\
\hline Platelets $\left(\mathrm{x} 10^{9} / \mathrm{L}\right)(\mathrm{n}=50)$ & $241.9 \pm 115.2$ & $246.9 \pm 138.1$ & 0.816 \\
\hline ALT $(\mathrm{IU} / \mathrm{L})(\mathrm{n}=54)$ & $58.2 \pm 33.1$ & $78 \pm 53.9$ & 0.001 \\
\hline Bilirubin $(\mathrm{mg} / \mathrm{dl})(\mathrm{n}=48)$ & $0.65 \pm 0.38$ & $0.64 \pm 0.35$ & 0.906 \\
\hline
\end{tabular}

Overall, the mean pre- and post-TCZ CRP was $18.7 \pm 10.7$ and $10.2 \pm 8.6 \mathrm{mg} / \mathrm{dl}$, respectively $(p<0.001)$. The $D$-dimer level decreased from $12.5 \pm 23.0 \mu \mathrm{g} / \mathrm{ml}$ to $10.3 \pm 12.2 \mu \mathrm{g} / \mathrm{ml}$ following TCZ $(p=0.643)$. There was a reduction in the proportion of neutrophils following TCZ $(88.6 \pm 14.8$ to $83.1 \pm 17.3$, $\mathrm{p}=0.01$ ). A significant increase was observed in ALT (58.2 \pm 33.1 to $78 \pm 53.9, p=0.001$ ), while bilirubin level did not show any significant change ( $0.65 \pm 0.38$ to $0.64 \pm 0.35, p=0.906)$. The differences in the pre- and post-TCZ LDH, TLC, Hb, and platelet count were not statistically significant (Table II).

Sub-group analysis showed that the mean pre- and post-TCZ CRP in the survivors was $18.0 \pm 10.3 \mathrm{mg} / \mathrm{dl}$ and $10.3 \pm 8.8 \mathrm{mg} / \mathrm{dl}$ $(p=0.003)$; while the pre- and post-TCZ CRP in the non-survivors, were $19.4 \pm 11.4 \mathrm{mg} / \mathrm{dl}$ and $10.1 \pm 8.7 \mathrm{mg} / \mathrm{dl}(p=0.005)$, respectively. 
Table III: Comparison of inflammatory markers and blood indices in survivors and non survivors.

\begin{tabular}{|c|c|c|c|c|c|c|}
\hline \multirow[b]{2}{*}{ Markers } & \multicolumn{3}{|c|}{ Survivors $(n=29)$} & \multicolumn{3}{|c|}{ Non-survivors $(n=25)$} \\
\hline & $\begin{array}{c}\text { Pre-TCZ } \\
\text { Mean } \pm \text { SD }\end{array}$ & Post $-\mathrm{TCZ}$ Mean \pm SD & P-value & $\begin{array}{c}\text { Pre-TCZ } \\
\text { Mean } \pm \text { SD }\end{array}$ & Post $-\mathrm{TCZ}$ Mean \pm SD & P-value \\
\hline CRP $(\mathrm{mg} / \mathrm{dl})$ & $18.0 \pm 10.3$ & $10.3 \pm 8.8$ & 0.003 & $19.4 \pm 11.4$ & $10.2 \pm 8.7$ & 0.005 \\
\hline D-Dimers $(\mu \mathrm{g} / \mathrm{ml})$ & $15.8 \pm 29.8$ & $11.4 \pm 10.6$ & 0.612 & $9.0 \pm 12.8$ & $9.2 \pm 14.1$ & 0.961 \\
\hline $\mathrm{LDH}(\mathrm{U} / \mathrm{L})$ & $723.3 \pm 355.6$ & $749.8 \pm 436.9$ & 0.594 & $716.5 \pm 253.1$ & $711.0 \pm 312.1$ & 0.930 \\
\hline $\operatorname{TLC}\left(x 10^{9} / \mathrm{L}\right)$ & $16.0 \pm 5.8$ & $13.3 \pm 5.0$ & 0.029 & $13.3 \pm 3.9$ & $13.9 \pm 5.2$ & 0.648 \\
\hline Neutrophils (\%) & $88.9 \pm 18.9$ & $80.9 \pm 20.7$ & 0.027 & $88.1 \pm 8.3$ & $85.6 \pm 12.2$ & 0.194 \\
\hline Hemoglobin (g/dl) & $13.3 \pm 2.0$ & $13.1 \pm 2.0$ & 0.445 & $13.0 \pm 2.2$ & $12.4 \pm 2.2$ & 0.136 \\
\hline Platelets $\left(\times 10^{9} / \mathrm{L}\right)$ & $255.9 \pm 103.0$ & $254.9 \pm 153.0$ & 0.971 & $226.7 \pm 127.5$ & $238.2 \pm 122.7$ & 0.739 \\
\hline ALT (IU/L) & $56.3 \pm 32.4$ & $78.0 \pm 51.0$ & 0.007 & $60.3 \pm 34.5$ & $78.1 \pm 58.2$ & 0.054 \\
\hline Bilirubin (mg/dl) & $0.69 \pm 0.38$ & $0.56 \pm 0.33$ & 0.061 & $0.61 \pm 0.37$ & $0.74 \pm 0.36$ & 0.060 \\
\hline
\end{tabular}

The drop in mean CRP level did not translate into mortality benefit. The pre- and post-TCZ LDH in survivors were 723.3 $\pm 355.6 \mathrm{U} / \mathrm{L}$ and $749.8 \pm 436.9 \mathrm{U} / \mathrm{L}(\mathrm{p}=0.594)$; while in non-survivors, these were $716.5 \pm 253.1 \mathrm{U} / \mathrm{L}$ and $711.0 \pm 312.1$ $\mathrm{U} / \mathrm{L}(\mathrm{p}=0.930)$, respectively. The pre and post-TCZ D-dimer in survivors were $15.8 \pm 29.8 \mu \mathrm{g} / \mathrm{ml}$ and $11.4 \pm 10.6 \mu \mathrm{g} / \mathrm{ml}$ $(p=0.612) ;$ while in non-survivors, these were $9.0 \pm 12.8$ $\mu \mathrm{g} / \mathrm{ml}$ and $9.2 \pm 14.1 \mu \mathrm{g} / \mathrm{ml}(p=0.961)$, respectively (Table III).

Sub-group analysis revealed that the 28-day mortality was (3/7) $42.9 \%,(9 / 26) 34.6 \%$, and (13/21) $61.9 \%$ in patients in the non-rebreather mask group, CPAP/BiPAP group, and mechanical ventilation group, which was statistically not significant $(p=0.172)$. The overall 28 -day mortality was $46.3 \%$.

\section{DISCUSSION}

The effects of TCZ on inflammatory markers, laboratory indices among the survivors and non-survivors of severe COVID-19 were evaluated in this study. TCZ demonstrated variable results in the inflammatory markers panel.

C-reactive protein has the characteristics of early rise and fall in relation to the degree of inflammation and disease severity. ${ }^{14}$ The mean difference in pre-TCZ and post-TCZ CRP of $8.4 \mathrm{mg} / \mathrm{dl}(\mathrm{p}<0.001)$ in this study, while Luo et.al from Wuhan, China reported a decline in CRP level from 119 to $113 \mathrm{mg} / \mathrm{dl}$ in TCZ-treated patients. ${ }^{12}$

This study revealed a decline in D-dimer level from $12.5 \pm$ $23.0 \mu \mathrm{g} / \mathrm{ml}$ to $10.3 \pm 12.2 \mu \mathrm{g} / \mathrm{ml}$ following TCZ ( $p=0.643)$, while Toniati et al. from Italy conversely reported a rise in Ddimers level. ${ }^{15}$ Insignificant differences in the pre-TCZ and post-TCZ LDH were found in the present study, similar to observations of Khiali et al. ${ }^{16}$ The mean change in inflammatory markers was not different between survivors and non-survivors.

Diabetes mellitus was the most frequent comorbid condition followed by systemic hypertension; while in the study by Guaraldi et al. and Toniati et al. from Italy, hypertension preceded diabetes mellitus. ${ }^{9,15}$ Identical to studies from
Guaraldi et al. and Luo et al., male predominance has been observed in the present study.

Progressive increase in mortality has been observed with a continuing decline in the oxygen saturation in severe COVID-19. ${ }^{17}$ Mortality of $60.9 \%$ in patients on mechanical ventilation was observed, which does not differ from the observation made by Alattar et al; ${ }^{18}$ while Toniati et al. has reported lower mortality (24\%) in TCZ-treated ICU patients. ${ }^{15}$

The adverse hematological events due to TCZ are inevitable. Anemia, thrombocytopenia, and neutropenia were noted with a mean difference of $0.3 \mathrm{~g} / \mathrm{dl}, 1.1 \times 10^{9} / \mathrm{L}, 5.0 \times 10^{9} / \mathrm{L}$, respectively. Alattar et al. observed anemia in $64 \%$ of patients. ${ }^{18}$ There was a rise in ALT in the post-TCZ group with a mean difference of $19.8 \mathrm{IU} / \mathrm{L}(p=0.001)$ in this study. A significant rise in ALT has been documented in COVID-19 patients treated with TCZ. ${ }^{19}$

All patients treated with TCZ were on concomitant glucocorticoids as standard therapy. The confounding effect of steroids on inflammatory markers has to be taken into account.

\section{CONCLUSION}

Overall, TCZ induced a significant reduction in CRP and percent neutrophils count; while the mean change in LDH, DDimers, TLC, and hemoglobin count was not substantial. Among survivors and non-survivors, the mean change in inflammatory markers was not statistically different.

\section{FUNDING:}

Hayatabad Medical Complex, Peshawar is a non-profit public sector hospital. The cost of tocilizumab and laboratory investigations were borne by the hospital.

\section{CONFLICT OF INTEREST:}

Authors declared no conflict of interest.

\section{ETHICAL APPROVAL:}

This study was approved by the Institutional Review Board and Ethical Review Committee of Hayatabad Medical Complex and Khyber Girls Medical College, Peshawar, Pakistan. 


\section{PATIENTS' CONSENT:}

Consent to participate in the study was obtained from the patients.

\section{AUTHORS' CONTRIBUTION:}

$S A, F R, S B, M N, A M, H G$ : Contributed to conceve the concept and devised the study design. Collected, reviewed and entered the data. Prepared the manuscript. All authors critically reviewed the final manuscript.

\section{REFERENCES}

1. Guan WJ, Ni ZY, Hu Y, Liang WH, Ou CQ , He JX, et al. Clinical characteristics of coronavirus disease 2019 in China. $N$ Engl J Med 2020; 382(18):1708-20. doi:10.1056/ NEJMoa2002032.

2. W.H.O. Virtual press conference on COVID-19 - 11 March 2020. http://www.who.int/docs/default-source/corona viruse/transcripts/who-audio-emergencies-coronavirus-press-conference-full-and-final-11mar2020.pdf?sfvrsn= cb432bb3_2. Published 2020. Accessed June 28, 2020.

3. Zhou F, Yu T, Du R, Fan G, Liu Y, Liu Z, et al. Clinical course and risk factors for mortality of adult inpatients with COVID-19 in Wuhan, China: A retrospective cohort study. Lancet 2020; 395(10229):1054-62. doi:10.1016/ S0140-6736(20)30566-3.

4. Xu X, Han M, Li T, Sun W, Wang D, Fu B, et al. Effective treatment of severe COVID-19 patients with tocilizumab. Proc Natl Acad Sci U S A 2020; 117(20):10970-10975. doi:10.1073/pnas.2005615117.

5. Fu B, Xu X, Wei H. Why tocilizumab could be an effective treatment for severe COVID-19? J Transl Med 2020; 18(1):1-5. doi:10.1186/s12967-020-02339-3.

6. Huang KJ, Su IJ, Theron M, Wu YC, Lai SK, Liu CC, et al. An interferon- $\gamma$-related cytokine storm in SARS patients. J Med Virol 2005; 75(2):185-94. doi:10.1002/jmv.20255

7. Siddiqi HK, Mehra MR. COVID-19 illness in native and immunosuppressed states: A clinical-therapeutic staging proposal. J Hear Lung Transplant 2020; 39(5):405-7. doi:10.1016/j.healun.2020.03.012.

8. Langer-Gould A, Smith JB, Gonzales EG, Castillo RD, Castillo JG, Ramanathan A, et al. Early Identification of COVID-19 Cytokine Storm and Treatment with Anakinra or Tocilizumab. Int J Infect Dis 2020; 99:291-7. doi:10.1016/ j.ijid.2020.07.081.

9. Guaraldi G, Meschiari M, Cozzi-Lepri A. Tocilizumab in patients with severe COVID-19: a retrospective cohort study. Lancet Rheumatol 2020; 2(August). doi:10.1016/ S2665-9913(20)30173-9.

10. Drug Regulatory Authority of Pakistan. Priority approval / registration of drugs during the covid-19 pandemic. http://www.dra.gov.pk/docs/Priority Approval_Registration of Drugs Remdesivir and Tocilizumab During the COVID-19 pandemic.pdf. Accessed June 8, 2020.

11. Sciascia S, Aprà F, Baffa A, Baldovino S, Boaro D, Boero R, et al. Pilot prospective open, single-arm multicentre study on off-label use of tocilizumab in patients with severe COVID-19. Clin Exp Rheumatol 2020; 38(3):529-32.

12. Luo P, Liu Y, Qiu L, Liu X, Liu D, Li J. Tocilizumab treatment in COVID-19: A single center experience. J Med Virol 2020; 92(7):814-8. doi:10.1002/jmv.25801.

13. World Health Organization. Clinical management of severe acute respiratory infection when COVID-19 is suspected (v1.2). 2020:1-21. http://www.who.int/publications-detail/ clinical-management-of-severe-acute-respiratory-infection-when-novel-coronavirus-(ncov)-infection-is-suspected.

14. Wang G, Wu C, Zhang Q, Wu F, Yu B, Lv J, et al. C-reactive protein level may predict the risk of COVID-19 aggravation. Open Forum Infect Dis 2020; 7(5):1-5. doi:10.1093/ ofid/ofaa153.

15. Toniati P, Piva S, Cattalini M, Garrafa E, Regola F, Castelli F, et al. Tocilizumab for the treatment of severe COVID-19 pneumonia with hyperinflammatory syndrome and acute respiratory failure: A single center study of 100 patients in Brescia, Italy. Autoimmun Rev 2020; 19(7):102568. doi:10.1016/j.autrev.2020.102568.

16. Khiali S, Khani E, Entezari-Maleki T. A comprehensive review of tocilizumab in COVID-19 acute respiratory distress syndrome. J Clin Pharmacol 2020; 60(9):1131-46. doi:10.1002/jcph.1693.

17. Nielsen Jeschke K, Bonnesen B, Hansen EF, Jensen JUS, Lapperre TS, Weinreich UM, et al. Guideline for the management of COVID-19 patients during hospital admission in a non-intensive care setting. Eur Clin Respir J 2020; 7(1):1761677. doi:10.1080/20018525.2020.1761677.

18. Alattar R, Ibrahim TBH, Shaar SH, Abdalla S, Shukri K, Daghfal JN, et al. Tocilizumab for the treatment of severe coronavirus disease 2019. J Med Virol 2020; (April). doi:10.1002/jmv.25964.

19. Salvatore Piano RV, Angeli P. Tocilizumab for severe COVID-19 pneumonia. Lancet Rheumatol 2020; 9913 (20):30284. doi:10.1016/S2665-9913(20)30284-8. 